\title{
Pesticide Contamination in Feed and Histopathological Properties of Bali Cattle Liver Slaughtered in Pesanggaran Slaughterhouse Denpasar
}

\author{
I Wayan Sudira ${ }^{1}$, Ketut Budiasa ${ }^{2}$, I Made Merdana ${ }^{3}$ \\ ${ }^{1}$ Laboratory of Physiology, Pharmacology, and Pharmacy, Faculty of Veterinary Medicine \\ Udayana University, Denpasar, Indonesia \\ Email: wayan.sudira@unud.ac.id \\ ${ }^{2}$ Laboratory of Physiology, Pharmacology, and Pharmacy, Faculty of Veterinary Medicine \\ Udayana University, Denpasar, Indonesia \\ Email: ketutbudiasa@unud.ac.id \\ ${ }^{3}$ Laboratory of Physiology, Pharmacology, and Pharmacy, Faculty of Veterinary Medicine \\ Udayana University, Denpasar, Indonesia \\ Email: $\underline{\text { imade_merdana@unud.ac.id }}$
}

\section{Corresponding Author: wayan.sudira@unud.ac.id}

\begin{abstract}
The number of crop pests that attack agricultural crops caused farmers to take precautions and treatment of crop cultivation by spraying using pesticides. Spraying action by using this pesticide also affects the grasses that grow around it which is a source of food for cattle. This study aims to evaluate basic data from the image of the liver of a Bali cattle that eats grass contaminated with pesticides and is slaughtered in the Pesanggaran slaughterhouse, Denpasar. Histopathological image of the liver of Bali cattle may vary, depending on the level of contamination of various pesticide ingredients that are eaten by the cattle. To see the histopathological changes in the liver of Bali cattle carried out by staining Hematoxylin Eosin (HE) and then it will be examined under a microscope. Observed changes that occur in the form of fatty degeneration, hemorrhage and necrosis. The study concludes is that cattle slaughtered in the Pesanggaran slaughterhouse, Denpasar come from various districts in Bali and the liver of Bali cattle slaughtered in the Pesanggaran Slaughterhouse, Denpasar are mostly exposed to pesticides characterized by histopathological features in the form of fatty degeneration, hemorrhagic and necrosis.
\end{abstract}

Keywords: Bali cattle, Liver, Pesticides, Necrosis

\section{INTRODUCTION}

The narrowing agricultural land and the number of pests and plant diseases, causing farmers to take action to prevent and treat their crops by spraying plants using pesticides. Pesticides can cause acute and chronic effects on agricultural workers and also exposed cattle. Exposure to pesticides can cause various effects, ranging from irritation to the skin and eyes to more deadly effects that affect liver damage, nerve workings, disrupt the reproductive hormone system, and cause cancer [1][2]. A study on 2007 showed non-Hodgkin's lymphoma and leukemia showed a positive relationship with 
pesticide exposure [1][3]. Strong evidence also shows that the negative effects of pesticide exposure include nerve damage, congenital abnormalities, fetal death, and disorders of the nervous system development. The American Medical Association recommends limiting pesticide exposure and starting to use safer alternatives.

The World Health Organization estimates that every year three million agricultural workers experience pesticide poisoning, and 18,000 of them die [4] and possibly 25 million people experience symptoms of mild pesticide poisoning every year. Women at 8 weeks' gestation age who live close to fields sprayed with dicofrol and endosulfan type organochlorine pesticides have the possibility of having children born with autism [5].

At this time information on the impact that appears on Bali cattle has not been widely reported. Seeing so many impacts that arise as a result of exposure to pesticides, the authors conduct this research by looking at the picture that appears on the liver of Bali cattle.

\section{MATERIAL AND METHODS}

\section{Research Design}

This study was an observational study and a cross-sectional design.
Samples were in the form of liver from 15 cattle originating from farms based on livestock and slaughtered at Pesanggaran Denpasar, Bali. In the survey, primary data collection was also conducted to farmers regarding the origin of slaughtered cattle and the source of feed consumed by the cattle concerned.

\section{The Object of Research and Sampling} Methods

The liver is taken from the Slaughterhouse (RPH) Pesanggaran, Denpasar, Bali. The liver preparations were carried out at the Pathology Laboratory, Faculty of Veterinary Medicine, Udayana University.

Liver Histopathology Properties Preparations

The liver is removed, then stored in a tissue cassette and fixed in $10 \%$ formalin solution. After fixation, a dehydration process is carried out with one session solution consisting of: $70 \%$ alcohol, $80 \%$ alcohol, 90\% alcohol, 96\% alcohol and absolute alcohol. After fixation, a clearing process using xylol is performed. The sample was infiltrated by blocking using an embedding set and then pouring liquid paraffin then cooling. In the cold blocks, sectioning is done using a microtome with a thickness of \pm 4-5 microns. The preparations on top of the object glass are soaked in each xylol solution for 5 minutes. Furthermore, the preparations are 
soaked in $100 \%$ alcohol each for 5 minutes. The preparations are put into distilled water and then soaked in Harris Hematoxylin (HE) for 15 minutes. Dipped in distilled water by lifting and lowering it. The preparation is dipped in $1 \%$ acid alcohol 7-10 times. Soak with distilled water for 15 minutes and put it into eosin for 2 minutes. The preparations were put in a series of alcohols ranging from $96 \%$ $100 \%$ each for 3 minutes to absolute ethanol for dehydration. The preparations are put on xylol twice for five minutes and dried for clearing and mounting the media. Histology preparations were observed with certain magnifications under a microscope and recorded microscopic changes were found.

\section{Variable}

The picture of liver histopathological changes is determined by mild category if the lesion is local, moderate category if the lesion is multifocal, severe category if the lesion is diffuse from the lesions of fatty degeneration, hemorrhage and necrosis.

\section{Data Analysis}

The histopathological change data of the liver were analyzed using qualitative descriptions.

\section{RESULTS}

\section{Survey Results of Cattle Slaughtered at RPH Pesanggaran Denpasar}

The survey results, based on the origin of the cows, the type of the feed, and the source of the feed are shown in Table 1.

Tabel.1 Survey Results of Cattle Slaughtered at RPH Pesanggaran Denpasar

\begin{tabular}{ccccc}
\hline $\begin{array}{c}\text { Cattle } \\
\text { Number }\end{array}$ & $\begin{array}{c}\text { Survey } \\
\text { Location }\end{array}$ & Regency & Feed Type & Origin of feed \\
\hline Cattle 1 & Banjarangkan & lungkung & Grass + Leaf + Concentrate & The Land Around \\
Cattle 2 & Aan & Klungkung & Grass + Straw + Leaf & Own Land \\
Cattle 3 & Dawan & Klungkung & Only Grass & The Land Around \\
Cattle 4 & Belantih & Bangli & Only Grass & Own Land \\
Cattle 5 & Tembuku & Bangli & Grass + Straw + Leaf & The Land Around \\
Cattle 6 & Apuan & Bangli & Only Grass & The Land Around \\
Cattle 7 & Pering & Gianyar & Grass + Straw + Leaf & Own Land \\
Cattle 8 & Saba & Gianyar & Only Grass & Own Land \\
Cattle 9 & Bakbakan & Gianyar & Only Grass & The Land Around \\
Cattle 10 & Petang & Badung & Grass + Leaf + Concentrate & The Land Around \\
Cattle 11 & Abiansemal & Badung & Grass + Straw + Leaf & The Land Around \\
Cattle 12 & Sedang & Badung & Grass + Leaf & The Land Around \\
Cattle 13 & Sesetan & Denpasar & Grass + Leaf + Concentrate & Own Land \\
Cattle 14 & Sanur & Denpasar & Only Grass & Own Land \\
Cattle 15 & Pedungan & Denpasar & Grass + Leaf + Concentrate & The Land Around \\
& & & & \\
\hline
\end{tabular}


Histopathological Properties of Bali Cattle Liver from Feed Contaminated with Pesticides that Slaughtered at RPH Pesanggaran Denpasar

From the 15 Bali Cattle slaughtered at the Pesanggaran $\mathrm{RPH}$, the liver was taken and histological preparations were made. The readings showed histopathological changes in the form of fatty liver tissue (fatty degeneration), hemorrhage, and necrosis. Histopathological data are presented in Table 2. Histopathological images are presented in Figs. 1 and 2.

Table. 2. Histopathological Changes in Bali Cattle Liver Organ from Feed Contaminated with Pesticides that Slaughtered at RPH Pesanggaran, Denpasar

\begin{tabular}{lccc}
\hline \multirow{2}{*}{ Sample } & \multicolumn{3}{c}{ Histopathological Changes } \\
& Fatty Degeneration & Hemorrhage & Necrosis \\
\hline Cattle 1 & Mild & Average & Average \\
Cattle 2 & Mild & Average & Average \\
Cattle 3 & Average & Mild & Average \\
Cattle 4 & Average & Mild & Mild \\
Cattle 5 & Average & Mild & Mild \\
Cattle 6 & Mild & Mild & Mild \\
Cattle 7 & Mild & Mild & Mild \\
Cattle 8 & Severe & Severe & Average \\
Cattle 9 & Mild & Severe & Severe \\
Cattle 10 & Mild & Average & Severe \\
Cattle 11 & Mild & Average & Average \\
Cattle 12 & Average & Mild & Mild \\
Cattle 13 & Severe & Mild & Mild \\
Cattle 14 & Mild & Mild & Mild \\
Cattle 15 & Mild & Average & Mild
\end{tabular}

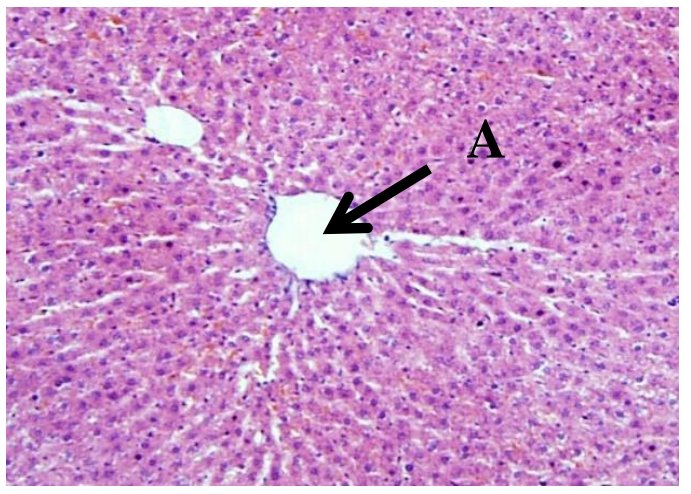

Figure.1 Histopathological picture of Bali cattle liver contaminated with pesticides (HE. 400X). A central vein was seen (A) and no changes in hemorrhagic lesions, congestion and necrosis were found.

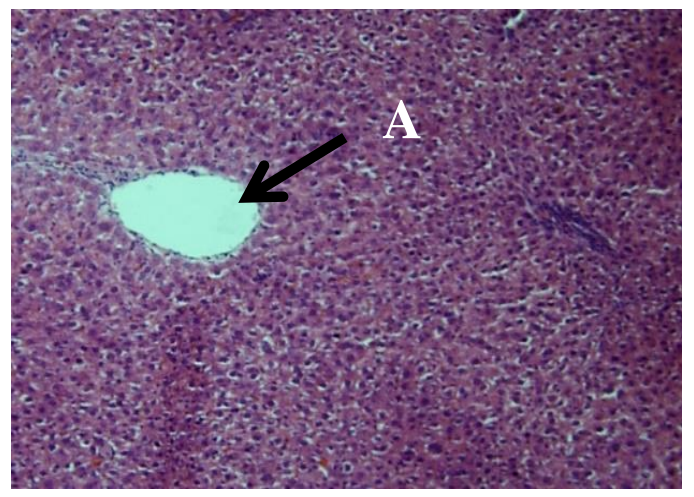

Figure. 2. Histopathological image of Bali cattle contaminated with pesticides (HE. 400X). There was a central vein (A) and there was no change in the lesions of hemorrhage, congestion, degeneration and necrosis. 


\section{DISCUSSION}

The availability of good forage in the field in each region is different, this adjusts to the season and soil conditions [6] suggesting the factors that must be considered in selecting good feed for cattle are the substances contained, the age of slaughter, and the level of soil fertility. Several breeders maintain cultivation grass, but most breeders provide field grass obtained from the surrounding area in the paddy fields and when the harvest season arrives most of the breeder's switch to utilizing unfermented agricultural waste as feed for their cows. The implanted agricultural waste has better nutritional content with higher crude protein content and feed digestibility compared to unfermented straw [7]. In difficult season grass and hay, some breeders use feed concentrates purchased from animal feed stores. In some districts surveyed applies as mentioned above.

Seeing the number of cows recorded from the questionnaire, it turns out that in each district, Klungkung, Bangli, Gianyar, Badung and Denpasar, the food sources are evenly distributed from agricultural areas in the surrounding area which are believed to have consumed food contaminated with pesticides. From interviews with several breeders, it was also revealed that cows ate grass and leaves that had been exposed to pesticides, although not directly. Farmers to maintain their rice and palawija always use pesticides.

Various pesticides can be grouped into families of chemical compounds. The well-known family of pesticide chemical compounds are organochlorines, organophosphates and carbamates. The organochlorine hydrocarbon family can be divided into dichlorodipheniletane (DDT), cyclodiene compounds, and others. Organochlorines work by disrupting the balance of potassium-sodium ions in nerve tissue. The level of poisoning of these compounds can vary, but all organochlorine compounds are persistent and can accumulate biologically. Organophosphates and carbamates have replaced organochlorines. Both inhibit the action of the acetylcholinesterase enzyme which sends acetylcholine to the nerve tissue, causing paralysis. Organophosphates are generally toxic to vertebrates [3].

Herbicides like phenoxy work selectively and only target broadleaf weeds and do not target grasses. Phenoxy and benzoic acid function much like plant growth hormones, and grow cells uncontrollably, so they enter the work of the plant transport system (phloem and xylem) and destroy them. Triazine interferes with photosynthesis. Glyphosate, 
which is currently widely used, has not been categorized in any of the herbicide compound families.

Pesticides can also be classified based on their biological mechanisms and methods of application. Most pesticides work by poisoning pests. Systemic pesticides are absorbed by plants and move within the plant, thereby poisoning pests that absorb plant nutrients. Insecticides and fungicides travel through xylem. Systemic insecticides can harm non-target insects, even beneficial insects such as bees and other pollinators, because systemic synecticides also move from the plant body to the flowers.

From the results of the above research, it can also be seen from the histopathological image that some of the liver shows fatty degeneration, hemorrhage and necrosis as shown in the results table. This occurs due to exposure to pesticides in most liver samples. This histopathological lesion variation depends on high and low exposure, this is in accordance with his opinion [8] and also depending on the condition of each individual cow.

This histopathological change occurs due to the presence of toxic substances that enter the body. The entry of pesticides into the body will be absorbed quickly from the gastrointestinal tract, transported through the portal vein to the liver [9]. The liver is the first organ that is exposed to pesticides from the gastrointestinal tract. The process of detoxifying pesticides partly occurs in the liver, and the liver converts them into products that can be excreted through urine and bile. The activity of the liver in converting and cleaning pesticides from the liver exposes it to toxic effects. This detoxification process causes damage to liver cells as a result of decreased function which can affect the metabolism of all organs. As a result of damage to liver cells leads to liver cell death [10].

In most of the cattle liver, changes in histopathological features were observed in the form of fatty degeneration, hemorrhage and necrosis with varying degrees. There is fatty degeneration, this occurs because of the accumulation of fat in liver cells, which is indicated by the presence of small vacuola-vacuola in the cytoplasm. This vacuole can enlarge and push the nucleus to the edge of the liver cells. When liver cells are damaged by various causes, then a series of changes are reflected in the liver [11]. Fatty degeneration occurs as a further response to hydropic degeneration, where cells are not able to metabolize fat properly, resulting in accumulation of fat in cells. Accumulation of fat in cells occurs when there is too much intake of free fatty acids 
into liver cells, the increase in lipid formation in liver cells is toxic [13].

According to [13] if too many toxic compounds are ingested so that they are toxic to the liver, then necrosis will occur which can damage liver tissue. Thus it is necessary to keep cows away from feed contaminated with pesticides.

\section{CONCLUSION}

Cows that are slaughtered at the Denpasar Pesanggaran RPH come from various districts in Bali. Most of the Balinese cattle liver slaughtered in the RPH Pesanggaran Denpasar were exposed to pesticides characterized by histopathological features in the form of fatty degeneration, hemorrhagic and necrosis. It is necessary to do further research on organs other than the liver to see the severity of pesticide exposure to Bali cattle slaughtered in the RPH Pesanggaran Denpasar.

\section{REFERENCE}

[1] Bassil KL, Vakil C, Sanborn M, Cole DC, Kaur JS, Kerr KJ (2007). "Cancer health effects of pesticides: Systematic review". Can Fam Physician. 53 (10): 1704-11. PMC 2231435. PMID 17934034.

[2] American Medical Association. (1997). Educational and Informational Strategies to Reduce Pesticide Risks. Preventive Medicine, Volume 26, Number 2
[3] Kamrin MA. (1997). Pesticide Profiles: toxicity, environmental impact, and fate. CRC Press.

[4] Miller GT (2004), Sustaining the Earth, 6th edition. Thompson Learning, Inc. Pacific Grove, California. Chapter 9, Pages 211216.

[5] Robert, et al 2007). Roberts EM, English PB, Grether JK, Windham GC, Somberg L, Wolff C. Maternal residence near agricultural pesticide applications and autism spectrum disorders among children in the California Central Valley. Environ Health Perspect. 2007;115(10):1482-9. doi:10.1289/ehp.10168. PMID 17938740. PMC 2022638. Lay summary: EHP, 2007.

[6] Salfina NA, Siswansyah DD, Swastika DKS.2004. Kajian Sistem Ternak Sapi Potong Di Kalimantan tengah. Jurnal Pengkajian dan pengembangan Teknologi pertanian 7 (20:155-170

[7] Matulessy DN, Kastanja A Y, 2013, Potensi Hijauan Bahan pakan ternak Di Kecamatan Tobelo kabupaten Halmahera Utara, Agroforestri8 (4):287-293

[8] Hegasy AMS, and Fouad U A 2014. Evaluation of Lead Hepatotoxicity: Histological, Histochemical and Ultrastructural Study. Forensic Med and Anat Res 2:70-79

[9] Chandrasoma, P dan Taylor, C.R.2005, Ringkasan Patologi anatomi, Jakarta.

[10] Mahli H, Gores GJ.2008 Cellular and Molecullar Mechanisms of Liver Injury, Gastrienterology. 134(6):1641-54.

[11] Arief.S, 2006 radikal bebas, bagian Ilmu Kesehatan anak FK Unair/RS.Dr. Sutomo Surabaya

[12] Chaevile, N.F. (1999). Intoduction to Veterinary Pathology.Iowa, USA, Iowa State University Press 
[13] Santosa, MH.2005 uji Toksisitas Akut dan Suakut Ekstrak etanol dan ekstrak Air Kulit Batang Artocarpus Champeden Spreng dengan Parameter Histopatologi Hati Mencit. Majalah Farmasi Airlangga 2005, m91-5 